\title{
Green Smart City as a New Paradigm of Local Development
}

\section{Zielone Inteligentne Miasta jako nowy paradygmat lokalnego rozwoju}

\author{
Ewa Łaźniewska*, Izabela Janicka**, Tomasz Górecki ${ }^{\star \star \star}$ \\ * Poznań University of Economics and Business, Department of Economic \\ and Local Government Policy, Poznań, Poland \\ E-mail (Corresponding Author): Ewa.Lazniewska@ue.poznan.pl, \\ ORCID: 0000-0002-2784-2190 \\ **University of Economics in Poznań, Department of Business Journalism and PR, \\ Poznań, Poland \\ E-mail: izabela.janicka@ue.poznan.pl,ORCID:0000-0003-4620-1935 \\ ***Adam Mickiewicz University, Faculty of Mathematics and Computer Science, \\ Poznań, Poland \\ E-mail: tomasz.gorecki@amu.edu.pl, ORCID: 0000-0002-9969-5257
}

\begin{abstract}
The idea of a smart city is widely discussed in literature but is associated to a lesser extent with the idea of moving towards a green smart city. Authors debate the critique of this type of approach and are of the opinion that climate change forces the construction of green models Like businesses, municipalities must be systematically assessed to identify assistance in terms of specialist advice or financial aid. The aim of this article is to develop the concept of a green smart city model, which may become a new development paradigm for municipalities. The article introduces the term eco-transformation in relation to the evolution of changes in the green smart city idea and proposes a tool to measure the action taken by municipalities in their pursuit of ecological maturity. The proposed models are universal in nature, i.e. they can be used to study other areas of a municipality's activity. Many areas in the model are debatable and difficult for municipalities to incorporate without a critical approach to many areas of knowledge, for example, of municipality management processes, technology, macroeconomic and mesoeconomic specificity, and behavioural analyses.
\end{abstract}

Key words: local development, sustainable development, smart cities, green smart city

\section{Streszczenie}

Idea smart city należy do szeroko dyskutowanych w literaturze, ale w mniejszym stopniu wiąże się ją z ideą dążenia do green smart city. Autorzy polemizują z krytyką tego typu ujęcia i są zdania, że zmiany klimatyczne wymuszają budowanie zielonych modeli. Podobnie jak przedsiębiorstwa gminy, muszą podlegać systematycznej ocenie służącej określenia poomocy w zakresie specjalistycznego doradztwa lub pomocy finansowej. Celem artykułu jest opracowanie koncepcji modelu green smart city, która może stać się nowym paradygmatem rozwoju dla gmin. W artykule wprowadzono termin eko-transformacji w odniesieniu do ewolucji zmian green smart city oraz zaproponowano narzędzie do pomiaru aktywności gmin w dążeniu do dojrzałości ekologicznej. Zaproponowane modele mają uniwersalny charakter tzn. mogą zostać zaproponowane do badania innych obszarów aktywności gminy. Wiele obszarów w modelu jest dyskusyjnych i trudnych do wcielenia przez gminy bez krytycznego podejścia do wielu obszarów wiedzy np. procesów zarządzania gminą, technologii, specyfiki makroekonomicznej i mezoekonomicznej, behawioralnych analiz.

Słowa kluczowe: rozwój lokalny, rozwój zrównoważony, inteligentne miasta, zielone inteligentne miasta 


\section{Introduction}

The topic presented in this article fits within what may be broadly understood as issues of sustainable and intelligent local development (Castaldi et al., 2008). The article presents the concept of a green smart city model, which may become a new development paradigm for municipalities. The concept of eco-transformation was introduced in relation to the green smart city evolution of changes and a tool was proposed for measuring the activity of municipalities in their pursuit of ecological maturity. These three terms constitute the value that the authors of this article might add to existing achievements in the area of regional development. The proposed models have a universal appeal. This article was written as a result of work on the Cross-border initiative for green smart cities / Grenzüberschreitende Initiative für grüne Smart Cities (GIGS) project, financed by the Foundation for Polish-German Cooperation.

Rapidly changing global trends in information and communication technologies raise questions as to what extent technologies (Gazzola et al., 2019) might play a pivotal role in shaping sustainable development. The vision of such development is rapidly evolving towards smart action. All over the world, cities are eagerly and successfully using ICT Information and Communication Technologies and the Internet of Things (Belli et al., 2020) to accelerate a variety of processes (Mora et al., 2018b). Rebuilding the G20 economies after the COVID-19 pandemic requires a new approach. Climate change and other environmental threats are likely to have a major impact on the G20 in the future. Investment in a viable and affordable green transition is crucial for these economies. A good starting point for further considerations would be to draw conclusions about what worked and what did not work from previous ecological revival efforts for the economy during the Great Recession of 2008-2009 by examining the cases of the United States and South Korea (Barbier, 2020). As a result of problems arising in relation to global warming, urban pollution, smog, noise, etc., it was necessary to change the way cities functioned (Dembicka-Niemiec, 2017). Recently, action along such lines has gained traction in cities around the world, including in Europe. Interest in environmental protection has grown and the concept of sustainable development involving smart, creative solutions has become more and more widespread.

Adopting the concept of smart growth does not have to mean a departure from the more traditional, ecological narratives that form the basis of sustainable development. Their aim is to find ways or better solutions to support modern lifestyles and thus to consolidate the existing status quo and increase the consumption of natural resources and energy, albeit in a more efficient way, rather than placing the environment at the centre of the policy-making process and at the core of planning interventions for sustainable development (Gazzola et al., 2019). One research objective of many authors is to answer this: to what extent do ecological and smart concepts overlap or move towards sustainable development?

Smart solutions usually have a social, economic and environmental dimension. Data integration provides a broader and faster insight into the resources, services and infrastructure that may better guide day-today operations, long-term planning and policy formulation for sustainable settlement (Bibri \& Krogstie, 2017). Some synergistic effects of such activities may include the elimination of planning process duplication, identification of existing data and knowledge gaps, and the determination of which planning areas and sectors should be coordinated and integrated to solve environmental problems and respond to social needs intelligently, thereby creating a sustainable socio-ecological system (Bibri \& Krogstie, 2017).

According to the authors of this article, it would seem necessary to aim the development of municipalities Pol: gmina in a direction that is not just smart city, but also green smart city. The close interdependence between ecology, technology and sustainable development provides a basis for monitoring this development and stimulating action. Taking into account the existing gap in the described research topic, a concept was proposed that would explain the dependencies between the municipality and its inhabitants, which could ultimately affect how the developmental needs of such municipalities are defined.

Within this concept, we suggest identifying four areas:

1) processes taking place in the municipality,

2) municipalities as an organisation,

3) technology,

4) the ecological behaviour of the residents.

The proposed model is dynamic; in other words, its components change over time. It is also relevant that all the areas outlined in the evaluation criteria may fluctuate quite significantly along with changes in the natural environment and human needs. The process that leads the municipality towards a smart green municipality is referred to as eco-transformation. In this case too is it possible to propose certain model stages, which may consequently determine the action that the municipality takes or will indicate what is going wrong in some areas. We can help individuals through expert assessments in outlining the type of support they require, analysing their needs, etc. The eco-transformation processes outlined create a model solution that is universal and may be applied in any municipality, but we also need to point out some research dilemmas related to this area. The conclusions formulated as a result of subsequent studies translate into recommendations for regional policy for business and local residents. The model sits within all new technological solutions related to the development of the digital economy. Its 


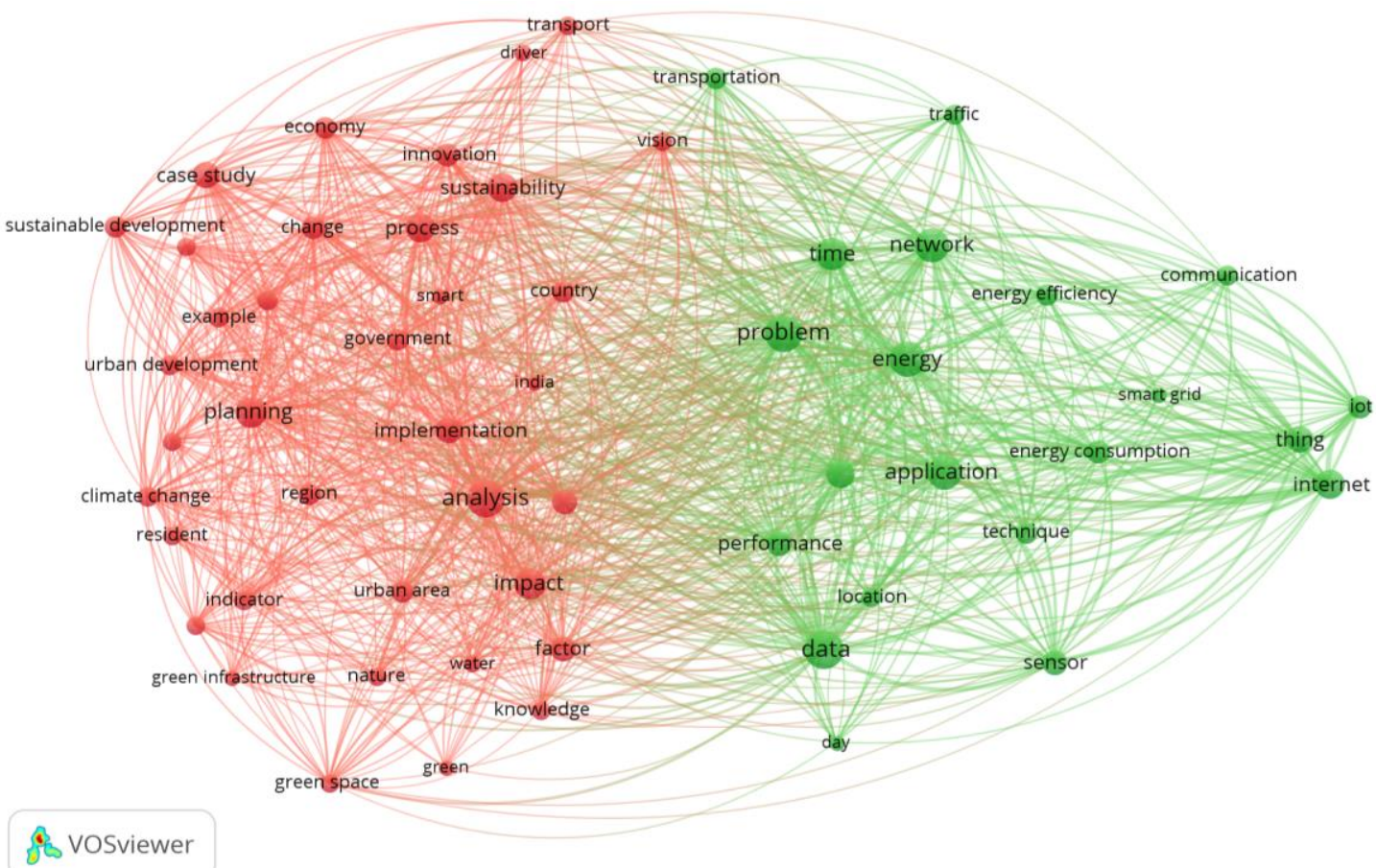

Figure 1. Thematic clusters identified on the basis of green smart city services between the years 2015-2020, source: own study

influence also extends into social aspects such as: environmental education, ecological awareness, social inclusion processes, etc.

The article focuses on the following three aspects: a critical analysis of achievements in the field of terminology characterising a green smart city, building a model of a green smart municipality and eco-transformation processes, determining the activity of municipalities in their pursuit of a green smart city as well as research dilemmas that emerge while building the model.

In the literature on the subject, we encounter various approaches to defining the issue of a smart city, although a concept gap exists regarding a unit that might be called a green smart city. In the context of civilisational progress and climate change, a need emerges to pinpoint such units in order to support their needs through socio-economic instruments $e . g$. allowances, subsidies, expert assistance, etc. and programmes depending on how far the processes have advanced in relation to the management of environmental goods e.g. water and waste management etc., the maturity of the municipality, the share of creativity and technology in contribution to the development of the municipality, etc.

Objective: 1. The first goal of the article is to build a model of ecological maturity for a municipality as a green smart city.

Objective: 2. The second goal is to define the ecotransformation process and build the individual stages of this process through the prism of four pillars: the municipality as an organisation, ongoing processes, technology and creativity as well as the residents and their ecological maturity.
Objective: 3 . The third goal is to propose a tool to study how a municipality may act towards its ecological maturity.

In the writing of this article, the research process included the following stages:

- bibliometric and critical analysis of the literature on the subject,

- defining a green smart city and the ecotransformation process,

- considerations related to research dilemmas,

- recommendations for further research.

\section{Bibliometric analysis of terms related to a green smart city}

The issues discussed in this article constitute a very young field from the point of view of how it links in with smart solutions in the area of local economy. It should also be emphasised that there are no publications in the literature databases that might approach the issue in a similar holistic way. An extensive collection of publications does exist in the area of sustainable development and smart cities per se. An analysis of the Scopus database for the years 20162020 using the keywords green smart city yielded 600 entries. Based on a search using the VOSviewer (ver. 1.6.6) software, a cluster map was assembled. There are two thematic clusters (Fig.1) that have very evenly distributed items when it comes to appearing keywords. It is clearly visible that most of this research work is interdisciplinary and combines IT knowledge with economics. Indeed, it is at the crossroads of different fields where work of particu- 
lar importance occurs in terms of discovering the relevant socio-economic paradigms mentioned in the presented article.

Towards a green smart city and the eco-transformation of the municipality

Contemporary city development strategies differ significantly from those several years ago in that they largely embrace creative and smart solutions (Singh, 2019). Globally, strategies, development visions, and city development plans include a number of successful ideas that are related to technology and ecology (Mora et al., 2019).

Despite the growing interest in the topic of smart cities (Anthopoulos \& Series, 2018), there is no universal definition of them, let alone green smart cities. The direction of ecological activities at various levels of the economy, including on the mesoeconomic scale - i.e. regional (Konecka-Szydłowska et al., 2019) and local (Orłowski, 2019) - is rooted in deteriorating environmental conditions and the need to limit or avoid harmful changes, but arises from people's attitudes, expectations and increased sensitivity to the quality of the environment. Regarding the diverse ways in which a smart city may be defined, the suggestion of certain developmental trends may also be observed. Such terms include city of knowledge, digital city and ecological city, which are used interchangeably in literature. Nevertheless, more and more people are trying to solve the problem of oversimplification of the smart city concept by offering holistic, multidisciplinary perspectives around the key areas of smart infrastructure, economy, mobility, governance, environment, etc. (Yigitcanlar \& Inkinen, 2018). Within the scope of the systematic efforts undertaken by various authors to develop a comprehensive common definition of smart cities (Anthopoulos \& Series, 2018), there is also a tendency to listen to people's voices when it comes to smart city design and decision-making, calling for direct participation from local actors and multiple stakeholders in planning and implementing social action, as well as technological and urban transformation for smart cities. However, serious questions arise concerning how this alternative approach - giving citizens a voice in smart city discourse - can be implemented in preexisting urban development processes using already available technological solutions (Pięta-Kanurska, 2017). This could in turn promote an alternative vision for smart cities that takes citizens' voices into account - a vision that is not compromised but achievable.

The common denominator of various definitions of a smart city are creative-minded residents. (PiętaKanurska, 2017), who can solve various problems by using modern technologies and also take advantage of information and communication technologies (ICT). In the literature, the definition of a smart city is often accompanied by sustainable development and the sharing economy (Durante \& Turvani, 2018). Innovative cities become more competitive (Szczech-Pietkiewicz, 2018) in the global space and more effectively meet the needs of their residents, i.e. in terms of quality of life. It should be emphasised that the popularity of the concept depends on financial support from the cities - e.g. through the availability of public funds - for instance, for the development of energy technologies, and the tendencies of global corporations (including Cisco, Google and IBM) to invest significantly in city digitisation projects.

Considering the various paths that constitute a smart city (Lazzeretti \& Oliva, 2018), one might also move towards a new term: green smart city. Looking at trends, needs, deteriorating living conditions in cities, climate problems, people's needs, etc., this is the direction that combines the most important developmental visions, helping residents to improve their quality of life. Smart also means innovative solutions based on knowledge and those involving local communities (Lee, 2019). Such models are also conducive to businesses, which are more willingly to locate their capital in green spaces. In particular, Industry 4.0 (Ciffolilli \& Muscio, 2018) aims for clean locations, as anything else may be hostile to the robots working there. Such examples may be found in Silesia (Klasik \& Kuźnik, 2017), where the reason for changing location was the polluted environment. The new concept of a green smart city, like a smart city, may be assumed not to be limited by features such as:

- territory,

- city size,

- the range of proposed solutions, e.g. e-government, smart transport, city services, open data in cities and many others,

- project size,

- $\quad$ source of financing.

By taking into account a smart city's spectrum of features and adding the term green to it, we can successfully attribute the following smart city traits to such a developmental paradigm (Łaźniewska, 2019):

1. The involvement of innovative processes that can take various forms: product-based, organisational, procedural, and marketingoriented. As the world population grows and consumption increases, the Earth's natural resources are shrinking, bringing climate change with it. This fact motivates us to create and introduce innovative technological solutions. Urban areas in particular are responsible for greater use of resources, resulting in a growing need for smarter infrastructures in search of a greener and more energy-efficient urban economy (Hancke et al., 2013).

2. The role of knowledge in the concept. Smart city concepts make use of all possible types of knowledge (Mora et al., 
2018a), which is crucial for the development of technological, social and economic processes. Knowledge is closely related to the institutions that operate within a given territory and cities with an established economic position have a real advantage in terms of numerous institutions operating in the field of science and knowledge.

3. The relevance of caring for the natural environment. There are cities - such as Vienna, Vancouver, Copenhagen - where the natural environment and sustainable development come first. Vienna promotes sustainable development and resource conservation through key strategies - Vienna's vision for a sustainable future in 2050 and an action plan for energy-efficient and climate-friendly urban development by 2020 .

4. Focus on competitiveness. This is one of the key elements of the development strategy of each smart and green city. In the model approach, competitive cities are those that attract modern clean technologies, providing their residents with jobs and ensuring good earnings. Especially in the case of economic competitiveness, the evolutionary nature of the concept is of great importance, which in practice means more and more competitiveness in terms of technological progress. In this case, of key significance are the role and activity of the city applied in the area of active business support and cooperation with businesses in order to build solutions that might boost the competitiveness of given centres.

5. Focus on the quality of human capital, impacting the city's development and also as a consumer of innovative solutions, is another important feature. For the development of an innovative city, it is important to foster a creative milieu, whose members generate more ideas therefore leading to the a greater likelihood that they will establish new innovative companies that will certainly create a variety of interesting solutions for innovative cities. Professions such as engineers, scientists, architects, as well as people involved in culture and the arts are more useful for the development of the city. Their activity is related to the creation of new services, products and often the generation of innovative processes.

Climate-related issues are part of all urban development strategies either directly or indirectly, yet vary greatly from city to city. It would seem to be highly relevant to meet the needs of eco-development and to propose solutions that fit in with the need to enhance the residents' standard of living by improving environmental conditions (Plac, 2020).
Like industry, municipalities are currently facing a number of challenges that can be identified as the common denominator of e-transformation. Ecotransformation processes seem to be the most important in the era of modern changes, much like etransformations. The sudden epidemic situation related to the covid-9 pandemic has made digital transformation a necessity rather than a choice (Folinas \& Metaxas, 2020). Unfortunately, municipalities do not always cope well with extremely difficult contemporary challenges (Churski, 2017). Organisational and financial gaps, the lack of appropriate skills amongst competent employees, as well as the low level of education (Jara-figueroa \& Bank, 2020) and involvement of residents affect regional differences in these processes. Taking into account the varied characteristics of the municipalities, e.g. resulting from their location on a national border, the challenges may turn out to cover a wide spectrum. In times of increasing ecological needs, the need to monitor the activity of municipalities in terms of ecological maturity is a very important challenge of the 21 st century, and one that should not be ignored. In the process of eco-transformation, municipalities strive for ecological maturity and this is achievable when the municipality does not violate the ecological balance, by combining economic and technological progress with sustainable development. This process will be evaluated and adapted according to environmental needs. We must remember that technologies are only a means for improvement, not the end in itself. We can define the conventional stages of reaching this maturity. In the case of the presented model, it has been specified on a five-level scale that marks the various stages of transformation, to be discussed later in the article.

Looking through the prism of the common features adopted, what will be of key significance for the municipality is the unique ability to eliminate the negative impact on the natural environment of its residents and tourists visiting the municipalities, the companies operating there, institutions in the business environment and the local municipal government itself. As mentioned previously, long-term, strategic activities within the municipality are highly relevant, resulting from the developmental directions adopted as well as other ongoing operations undertaken ad hoc. The municipality should be committed to continuous improvement through appropriate management of change, risk, knowledge and ideas. The authorities should be open to bold proposals, frequently question the current state of affairs, and propose alternative solutions. Civil servants should be encouraged to work as a team on ecological projects that to a large extent require them to feel the situation, e.g. by using the Design Thinking Method.

A crucial element in the municipality's drive to achieve a high level of ecological maturity is a strat- 


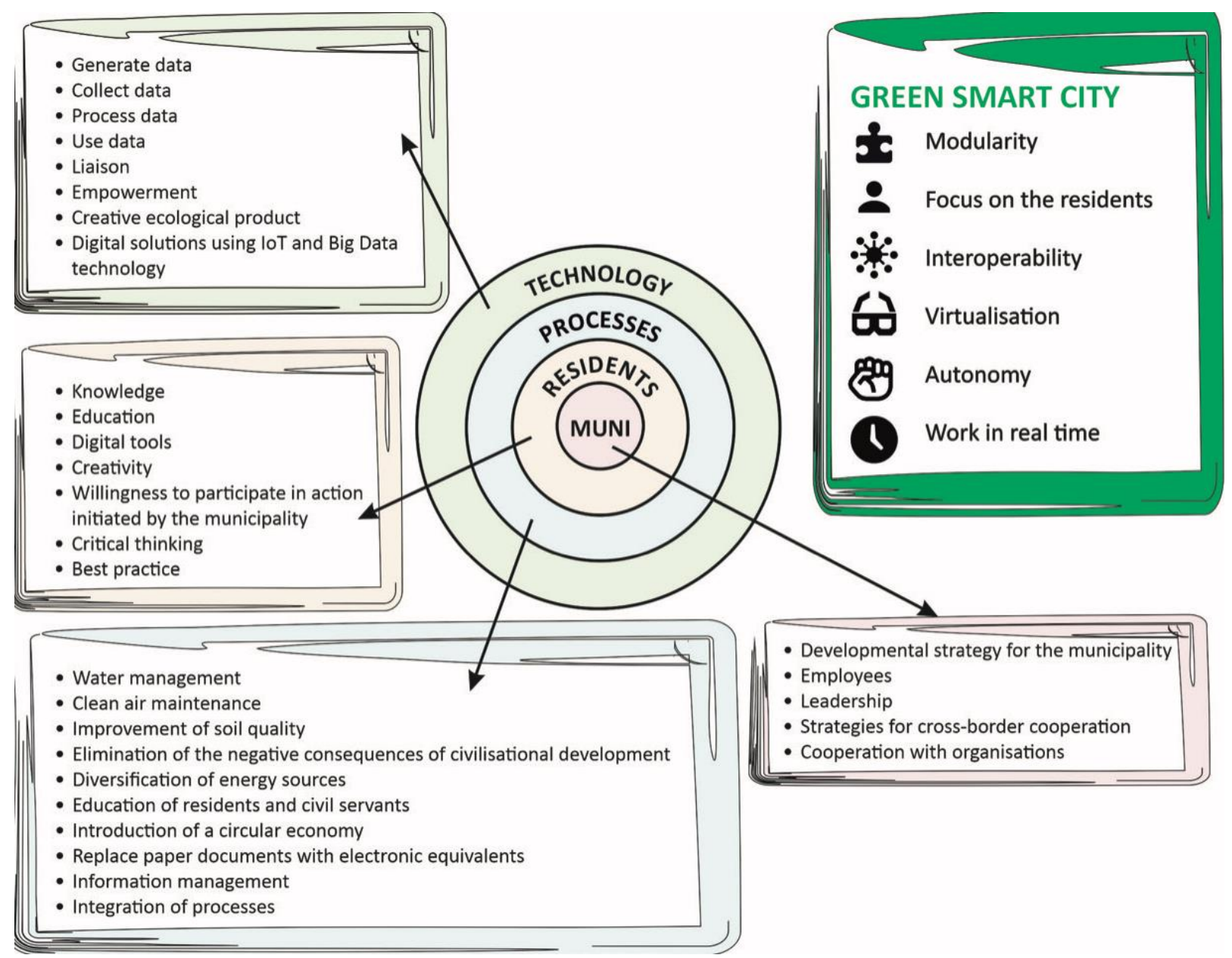

Figure 2. The green smart city model, source: Own study

egy of ecological development that makes use of smart digital solutions. It is important, on the one hand, to monitor achievements, and on the other hand, to ensure that the emerging new digital solutions are combined with interesting business models that will prove useful in various digital solutions adopted in municipalities. A key task facing the municipal authorities is the necessity for the municipality to cooperate with its residents. Digital solutions have an advantage over others, especially since they offer the possibility for digital products to be personalised, which in turn presents some very interesting opportunities, e.g. related to the area of energy, water or municipal waste management. Appropriate solutions, which are conventionally referred to as smart, allow for excellent cross-linking and monitoring of processes and the implementation of improvements that solve problems in a highly personalised manner. The development of solutions or identification of problems should involve groups of specialists who work with the design method.

Analysis of the municipality's activity in the area of ecological maturity is visible on many levels. In our adopted model, this analysis will deal with the following four areas: the municipality as an organisation, relations with residents, the inhabitants of a given municipality, technology and creativity along with processes relevant to the municipality's pro ecological endeavours. It should be noted that both the technologies used by the municipality and the silent knowledge of the local community are very important for the model. On the one hand, it can be a barrier against initiatives or, on the other hand, an impulse for new projects.

The second figure shows the elements that comprise the green smart city model. Of course, this is not a closed model. It can be enriched with various components that may arise from the current state of knowledge, technology or changing socio-economic factors. Certain fields may also be supplemented. The first element of this model is the municipality as an organisation. It differs significantly from an enterprise in terms of structure, types of relationships, leadership features, method of financing, speed of changes, technologies used in solving problems, and above all, a mission and strategy that is focused on the residents. What connects the municipality and an enterprise is the pursuit of transformation by increasing the skills of employees, improving qualifications, know-how and creativity. All these features are indispensable for solving problems using digital tools based on the design method. This perspective 
does not entail the need to transform the city's administrative structures. The decision-making process is made more innovative by using a network of technologies that consists in collecting all types of data and information regarding public management by sensors and networks of sensors, i.e. creating databases.

The literature distinguishes four perspectives of modern city management and rationality in decision-making (Meijer \& Bolívar, 2016):

- The first perspective, i.e. administrating a smart city, is characterised by a low level of transformation. The local government must approve the city's development as a smart city, and at most it can promote or prioritise some of its areas or districts.

- The second perspective emphasises the need to make smart decisions and implement them. This perspective is not associated with the need to transform the city's administrative structures, but rather changes in the way decisions are made. The decision-making process is made more innovative by using a network of technologies.

- The third perspective in smart governance means creating new administrative structures, so-called smart administration. It is a new form of electronic governance that uses advanced information technologies to connect and integrate information, processes, institutions and physical infrastructure to better serve the urban community.

- The fourth perspective called smart governance requires the greatest transformation in city administrative structures. This means smart urban collaboration between various actors in the city and cooperation between local government administration departments, as well as with the community, facilitating the promotion of economic growth and undertaking endeavours mainly oriented towards the citizens. Smart urban collaboration is based on proactive structures within the city administration involving all actors within a conurbation. Such an approach maximises the socio-economic potential of the city while taking into account its ecological development. This proves decisive in the process of counteracting negative external factors and eliminating long-term historical circumstances and psychological barriers.

Another element of the model are the processes that the municipality should manage that are involved in improving the state of the natural environment, thus implementing the principle of sustainable development. Becoming a smart city is one of the top priorities on the agenda in many European cities. Among the different strategies along the path of transformation, local governments strive to introduce innovations in their cities, for example by encouraging international enterprises to bring their green energy services and products to their municipalities. Knowing how to attract these businesses means that local leaders understand the multi-criteria decision problem faced by enterprises from various sectors such as energy, when deciding to expand to one city or another. These types of processes should be thoroughly identified and underpinned by knowledge.

Of key importance is the degree of integration of process management, as the processes in question may be fragmented in larger units. The issue of cooperation and communication with residents is equally significant. To this end, green projects inter alia are established within participatory budgets. Standardisation is a very topical element of these processes, and is particularly meaningful for residents, because it creates a new quality in relations with them and promotes the introduction of digital solutions, information exchange, etc. Process management involves areas such as: water management, maintaining air purity, improving soil quality, eliminating the negative consequences of civilisational development, diversification of energy sources, education of residents and office workers, introduction of a circular economy, replacing paper documents with e-documents as well as the very important process of information management.

Another very significant component of the model are the residents. Their role in the ecological transformation of the municipality focuses on their knowledge resources, creativity, sense of connection and identification with the municipality, ecological awareness, and willingness to achieve a certain standard of living. They expect the municipality to initiate various solutions that will help to combat ecological problems, e.g. bicycle paths, recycling of rubbish, access to the Internet, available cheap and convenient public transport. Of key relevance for the further development of the municipality is a wellthought-out strategy of communication with the residents, which may boost their activity in city life. This may succeed in mobilising the residents and building interpersonal relations. Social media are used in business. Polish cities, unlike businesses, tend to lag way behind when it comes to using tools such as crowdsourcing (Sobol, 2017). The residents themselves are willing to participate in the implementation of good ecological projects, but they must be environmentally conscious residents. Smart people force greater changes and accelerate green transformation. What is useful from the municipality's point of view are activities aimed at encouraging residents to actively participate in green and sustainable 
solutions that enhance the attractiveness of the municipality in the long term. Conscious users focusing on ecological housing and living solutions ensure high quality. The use of online platforms as well as community activity on the Internet also forms the basis of the crowdfunding concept. Through financial involvement in local bottom-up projects, crowdfunding complements the investments implemented by the city (Sobol, 2017). The municipality's acceptance and openness to bottom-up solutions suggested by the residents create a coherent system of interdependent needs and expectations.

Consideration should also be made concerning whether the residents are ready to be smart in their daily relations with the city. For this to happen, it is necessary to educate residents and introduce marketing activities that might encourage conscious use of the digital solutions offered by the municipality. The use of digital tools should be especially visible among young people, because they are the largest user group of various digital products. One may also wonder if they are also aware of the digital solutions on offer as city residents. The reality, however, as can be observed from research conducted in Poznań, is completely different. A survey was conducted in October 2019 on a group of approximately 2,000 students studying in Poland at Poznań universities at technical and economic faculties. It can be argued that they constitute, in a sense, a representative indication of trends and changes in the near future. During the survey, students were asked about major nuisances related to living in the city. Problems with transport (personal and public) came to the fore, with relatively little interest in matters such as dirty public spaces or insufficient green areas and recreational areas in the city. It is clear, however, that these problems were worth pointing out for a significant number of those questioned, i.e. they are quite relevant from the point of view of the average person. The introduction of new information tools in the most pressing areas would certainly improve the situation. Apart from traditional social media like Instagram, Facebook, Messenger, almost half of the respondents also indicated the Poznań public transport system and agglomeration card services $P e K a$ as well as ticket applications JakDojadę?/ When I Arrive? And Mobilet. Applications that help to locate services, recreational facilities or city bikes enjoy similar popularity. Therefore, it should be concluded that smart services are a highly desirable means of assisting city navigation, although only half of the respondents associate them with the city, and most see them through the prism of external companies. At this point, it is worth noting that most of the services are not related to the sustainable development of the city, which can undoubtedly be an important signal to take corrective measures.

The development of technology is a highly significant element of the described model. Big Data
(Tabakow, M., Korczak, J., Franczyk, 2014) and the evolution of the Internet of Things (IoT) played a major role in the implementation of the smart city strategy (Cellary, 2019). Large data sets enable cities to obtain valuable information from a variety of sources, and the Internet of Things facilitates the integration of sensors, and the identification of radio frequencies and bluetooth in the actual environment. There are many applications for the IoT in smart cities (Cellary, W., 2018). Examples include smart parking lots, traffic control, lighting, waste management, park hosing, flood warning systems, monitoring systems for buildings and infrastructure, as well as smart air quality monitoring systems.

The analysis of data generated by devices operating in the IoT is a great challenge that both Big Data researchers and businesses themselves will have to face. Regarding data generated by smart devices, according to the Cisco report (Cisco.Com, 2020) it is estimated that by 2023 more than 29 billion devices will be connected to the IoT network, which in fact are an example of Big Data of a different type than those that we produce today on the traditional Internet.

The application of statistical and analytical methods will be essential to understanding such large data sets. It might seem that when using Big Data, we already know everything and we can abandon traditional statistical methods, in which a major role is played by care for data quality, sample selection or uncertainty, among others. Meanwhile, if we want to draw conclusions about the entire population - for example, on the basis of data from Facebook - we should take into account that young people are far more likely to be users. It turns out that statistical methods such as time series analysis, cluster analysis, dimension reduction methods, classification or regression are necessary for Big Data analysis. On the other hand, such large amounts of data give some machine learning methods a chance to shine, since they only really reveal their true capability when they have huge learning sets at their disposal. Such techniques include, for example, deep neural networks (Bengio, Y., Courville, A., Goodfellow, 2018), which have become extremely popular in recent years.

With regard to the model itself, the research dilemma stems from the complexity of the individual areas analysed in the green smart city model itself. Four such areas have been identified, which consist of a number of factors subject to assessment. A question arises here regarding the indicators, universal measures and problems with the comparability of these measures. Our research experience also raises the problem of adapting measures to macroeconomic development and, consequently, the historical conditions of this development, as well as the level of socio-economic development. 


\section{Stages of ecological maturity}

The stages of a municipality's ecological maturity are related to its transformation in various areas: technology, the type of organisation that the municipality is, the residents, processes to an open green smart city that make use of internationalisation of processes, integration of processes, orientation towards residents and improving the quality of life for these residents. An open municipality that creates new spaces for living and economic development also faces the self-assessment of its activity in the field of ecology. Through questionnaire research, it is possible to determine at what stage of development a municipality is. We need to find out what instruments it uses, in which areas it is particularly active, in which areas it has developmental deficits, what strategies it adopts, etc. This represents a great deal of knowledge, considering the multitasking nature of municipalities. The criteria for this evaluation must be adapted to the level of national economic development and must evolve in line with technological progress. The question of encouraging people to take action is relevant, in order to think in terms of developmental challenges, i.e. eco-transformation processes. The tool that is to be used for this purpose is referred to as the measurement of the municipality's ecological activity in striving for ecological maturity. This is a third element, which is integral in the adopted concept of a green smart city.

In accordance with the state of knowledge, the technologies that define the framework of this model may evolve in the future. The following features have been indicated:

1. Modularity, meaning that the applied solutions are universal and can be used in other municipalities,

2. Openness to residents' initiatives, meaning that the residents are included in decision-making processes and willingly take part in participatory initiatives, such as a participatory budget, or marking problem points on a map,

3. Interoperability, i.e. the compatibility of the proposed systems with other similar solutions,

4. Virtualisation, i.e. moving most data and operations to a virtual space, offering tremendous benefits in terms of easy access to information, speeding up the process of making strategic decisions in the municipality, etc.,

5. Applied solutions based on autonomous (maintenance-free) solutions, possibly including solutions for public transport, waste management, and water resources etc.,

6. Working in real time - a very important feature of this system - using the capabilities of modern technologies, and of personal communication devices in particular, to allow for better problem solving, both in terms of communication flow from the city to citizens and collecting feedback.

The main research dilemma is also the measurability of the term green smart city, the number of categories, the breadth of the research scope and the standardisation of qualitative research. The variety and heterogeneity of municipalities' action in favour of the needs of their residents makes it difficult to maintain the principle of universality, while personal influences and the relativism of answers remain unavoidable in closed questions. The departure from the statutory obligations of the municipality strengthens the discretion and often misinterpretation of the phenomena under evaluation. Due to the utilitarian nature of the study, it is worth assessing two participants: the municipality and the residents.

In terms of action undertaken, five development stages have been distinguished. The individual stages are shown in Figure 4, Eco-transformation processes.

An active municipality is one that implements ecological and economic solutions with varying results, because it encounters a number of obstacles and difficulties. It could be much more active, but there is no maturity in the area of technology, process, as well as resident activity and creativity. The municipality is also organisationally weak. Many processes overlap, with no transparency in terms of competences, project approach, creativity in action; featuring an inability to find the right business models for municipal projects, a lack of a clearly defined development vision, strategy, etc. The needs of such municipalities are huge and it is necessary to support them by accurately identifying their requirements, gaps, obstacles, and environmental problems. The grouping and systematisation of these phenomena will allow for a gradual transition to higher stages.

The next stage is a creative municipality, much more involved in ecological development processes than an active municipality. It has digital and other solutions at its disposal that do in fact meet some of the residents' expectations. Unfortunately, these solutions are often random and have no logical consistency. They do not create harmonious systems that significantly reduce ecological problems. Again, help is needed to maximise the benefits of these different solutions.

A municipality that includes its residents is one that assesses its added value through the prism of the residents' high level of involvement in developmental processes. The benefits of this approach are farreaching and result from better identification of problems, benefits that match solutions to the needs of the residents, residents who identify with the municipality, which has a positive effect on the image of the municipality, etc. By joining the development processes, the residents strengthen the municipality 


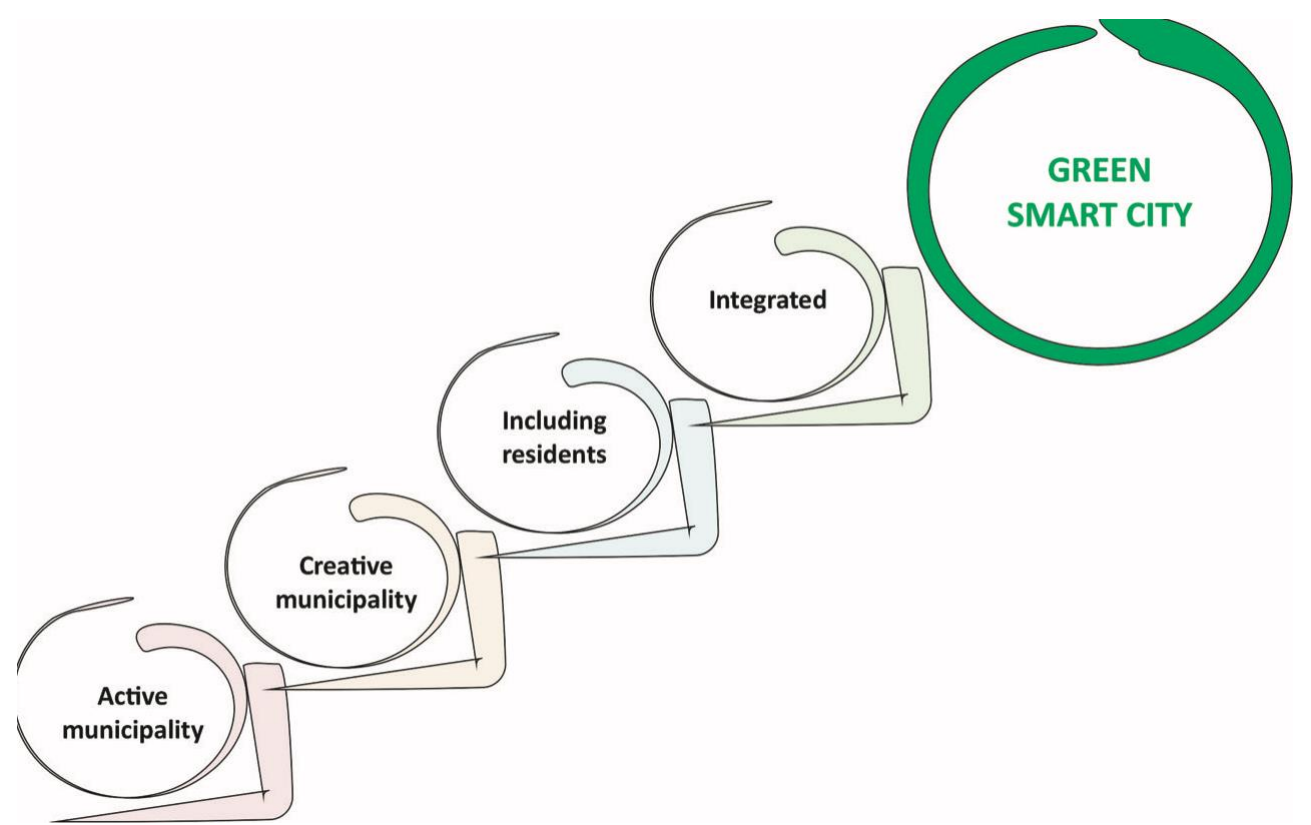

Figure 4. Eco-transformation processes, source: own study

with their knowledge, competences, investment decisions, etc.

An integrated municipality is one that has noticed the benefit from the integration of processes, internationalisation and standardisation, and willingly implements smart projects integrated into larger joint ventures, e.g. regarding mobility, waste or water management.

A green smart city is the highest level, and most open to new solutions and cooperation. Resistant to external factors. In the case of municipalities located near national borders, the socio-economic added value in municipalities becomes apparent by mobilising endogenous potential by strengthening the local potential as partners and initiators of cross-border cooperation, participation of economic and social entities, environmental organisations and tourist agencies (Ramírez, 2000). A relevant issue is the improvement of professional qualifications and environmental competences, additional development, e.g. in the field of infrastructure, transport, tourism, the natural environment, education, research and cooperation between small and medium-sized enterprises.

Taking into account the tremendous complexity of the entire ecosystem of the municipality, it is necessary, on the one hand, for the municipality to selfevaluate by means of tools that may determine their level of activity, while on the other hand it would seem indispensable to enlist the help of professionals who can prepare specific instruments to support particular areas of the municipality's work. It should be noted that not only financing is necessary here, but also the identification of specific gaps, niches and proposals for solutions to some problems. In terms of self-assessment, we suggest an instrument that may be called an evaluation of the municipality's activity towards its ecological maturity. Such an instrument is ready to implement and is the subject of another publication of ours.

\section{Summary}

The considerations broached in this article may lead one to reflect that there is an urgent need to direct municipalities towards combining the benefits arising from the use of digital tools with attention to solutions that serve the environment. In the course of the discussion on what contemporary municipalities should do in the context of climate requirements, the achievements of municipalities should be monitored in terms of their ability to deal with contemporary developmental problems. In view of the climate challenges faced by municipalities, it is important to adapt quickly to the changing circumstances. They must follow two paths - i.e. propose smart solutions combined with sustainable development.

We emphasise that this is a model whose components must be adapted to the level of macroeconomic development of the economy and go hand in hand with technological progress. When implementing their ecological mission and goals, municipalities pass through a process of eco-transformation, which is closely related to e-transformation. Surveys can be used to measure a municipality's progress in the ecotransformation process. The ecological maturity stages of a municipality have been included in a fivepoint scale and mainly involve maturity levels. We intend to devote another publication to these issues. The added value resulting from the study of municipal action in pursuit of ecological maturity is manifested in: 
education of municipalities and residents, cognitive aspects,

implications for regional policy,

implications for cross-border cooperation in terms of ecology,

identification of developmental niches and implications for businesses in terms of investment opportunities in a given area, guidelines for formulating further directions of development and adaptation of specific solutions,

influence on the paradigm shift of process management in the municipality, from searching for the causes of changes in the natural environment to identifying the processes at a given moment (through the available information) for the extrapolation and anticipation of future changes.

Taking into account the considerations proposed in this article, we can also refer to a number of terms that may seem to be controversial and difficult for municipalities to incorporate without a critical approach to many areas of knowledge, e.g. municipal management processes, technology, the macroeconomic and mesoeconomic specifics, and behavioural analyses .

Further research is recommended to extrapolate individual areas within the model. The proposed green smart city model may indicate different elements depending on the economic realities in which the municipalities operate.

Acknowledgement. The article is a result of work on the project entitled: Transgraniczna inicjatywa dla zielonych smart cities/Grenzüberschreitende Initiative für grüne Smart Cities (GIGS), financed by the Foundation for Polish-German Cooperation.

\section{References}

1. ANTHOPOULOS L. G., 2018, The Rise of the Smart City, Understanding Smart Cities: A Tool for Smart Government or an Industrial Trick?, ed. Anthopoulos L.G., Springer, p. 5-45.

2. BARBIER E. B., 2020, Greening the Post-pandemic Recovery in the G20, Environmental \& Resource Economics: 685-703.

3. BENGIO Y, COURVILLE A., GOODFELLOW I., 2016, Deep Learning, MIT Press.

4. BIBRI S. E., KROGSTIE J. 2017, The core enabling technologies of big data analytics and context-aware computing for smart sustainable cities: a review and synthesis, Journal of Big Data, 4(1): 1-50.

DOI: 10.1186/s40537-017-0091-6.

5. CELLARY W., RYKOWSKI J., 2018, Challenges of Smart Industries - Privacy and payment in Visible versus Unseen Internet, Government Information Quarterly, 35: S17-S23. DOI: j.giq.2015.08.005.

6. CHURSKI P., 2017, Regional contracts in the Polish development policy, Quaestiones Geographicae, 37(2): 93-108. DOI: 10.2478/quageo-2018-0016.

7. CIFFOLILLI A., MUSCIO A., 2018, Industry 4.0: national and regional comparative advantages in key enabling technologies, European Planning Studies, 4313: 1-21. DOI: 10.1080/09654313.2018.1529145.

8. DEMBICKA-NIEMIEC A., 2017, City of the Future on the Background of the Sustainable Development, Prace Naukowe Uniwersytetu Ekonomicznego We Wroctawiu, 490: 190-197.

DOI: 10.15611/pn.2017.490.17.

9. DIJKSTRA L., GARCILAZO E., MCCANN P., 2015, The effects of the global financial crisis on European regions and cities, Journal of Economic Geography, 15(5): 935-949.

DOI: $10.1093 / \mathrm{jeg} / \mathrm{lbv032}$.

10. DURANTE G., \& TURVANI M., 2018, Coworking, the Sharing Economy, and the City: Which Role for the 'Coworking Entrepreneur'?, Urban Science, 2(3). DOI: $10.3390 /$ urbansci2030083.

11. FOLINAS S., METAXAS T., 2020, Tourism: the Great Patient of Coronavirus Covid-2019, International Journal of Advanced Research, 08(04): 365375. DOI: 10.21474/ijar01/10788.

12. GAZZOLA P., DEL CAMPO A. G., ONYANGO V. ,2019, Going green vs going smart for sustainable development: Quo vadis?, Journal of Cleaner Production, 214: 881-892.

DOI: $10.1016 / j$.jclepro.2018.12.234.

13. HANCKE G. P., DE SILVA B. de C., HANCKE G. P., 2013, The role of advanced sensing in smart cities, Sensors (Switzerland), 13(1): 393-425. DOI: $10.3390 / \mathrm{s} 130100393$.

14. JARA-FIGUEROA C., BANK I. D., 2020, Local labor markets and higher education mismatch Local labor markets and higher education mismatch, IDB Working Paper Series No IDB - WP - 01115: 22-37. DOI: $10.18235 / 0002295$.

15. KLASIK A., KUŹNIK F., 2017, Regiony wobec wyzwań przyszłości, Zeszyty Naukowe Uniwersytetu Ekonomicznego w Krakowie, 1(961): 5-19.

DOI: 10.15678/znuek.2017.0961.0101.

16. KONECKA-SZYDŁOWSKA B., CHURSKI P., HERODOWICZ T., PERDAŁ R., 2019, Europejski kontekst wpływu współczesnych megatrendów na rozwój społeczno-gospodarczy. Ujęcie syntetyczne, Przegląd Geograficzny, 91(2): 39-59. DOI: 10.7163/PrzG.2019.2.3.

17. LAZZERETTI L., OLIVA, S., 2018, Rethinking city transformation: Florence from art city to creative fashion city, European Planning Studies, 0(0): 1-18. DOI: 10.1080/09654313.2018.1478951.

18. LEE N. , 2019, Inclusive Growth in cities: a sympathetic critique, Regional Studies, 53(3): 424-434. DOI: $10.1080 / 00343404.2018 .1476753$.

19. ŁAŹNIEWSKA E., 2019, Aktywność miasta Poznania na drodze do smart city, Rozwój Regionalny i Polityka Regionalna, 48: 105-117.

20. PIĘTA-KANURSKA M.,, 2017, Wehikuły rozwoju współczesnych miast. Wyzwania dla Wrocławia, Studia KPZK PAN, CLXXVII: 185-188. DOI: $10.24425 / 118581$.

21. MĄCIK R. , 2016, „Internet rzeczy” - postrzegane przez młodych konsumentów korzyści i zagrożenia wyniki badań wstępnych, Przedsiębiorczość $i$ Zarzqdzanie, 17(4): 11-27.

22. MEIJER A., BOLÍVAR M. P. R., 2016, Governing the smart city: a review of the literature on smart urban governance, International Review of Administrative Sciences, 82(2): 392-408. DOI: $10.1177 / 0020852314564308$. 
23. MORA L., DEAKIN M., REID A., 2018a, Smart-city development paths: Insights from the first two decades of research. Green Energy and Technology, Springer. DOI: 10.1007/978-3-319-75774-2_28.

24. MORA L., DEAKIN M., REID A., 2018b, Smart and Sustainable Planning for Cities and Regions, Springer. DOI:10.1007/978-3-319-75774-2.

25. MORA L., DEAKIN M., REID A. , 2019, Strategic principles for smart city development: A multiple case study analysis of European best practices, Technological Forecasting and Social Change, 142: 7097. DOI: 10.1016/j.techfore.2018.07.035.

26. ORŁOWSKI A. , 2019, Model gotowości procesowej urzędu miejskiego dojścia do smart city, CeDeWu.

27. PLAC K., 2020, Klimat jako obszar interwencji strategicznej w rozwoju miast, Biblioteka Regionalisty, 20: 2-20.

28. RAMÍREZ M. G., 2000, Institutionalisation of CrossBorder Cooperation: The Role of the Association of
European Border Regions, Borders in Central Europe After the Schengen Agreement, p. 93-102.

29. SENKUS P., SKRZYPEK A., ŁUCZAK M., MALINOWSKI A., 2014, Internet of Things: przeszłość teraźniejszość - przyszłość: Seria Administracja i Zarzadzanie, 30(103): 163-172.

30. SINGH A. , 2019, Smart City-Case studies, March, DOI: $10.5281 /$ zenodo.2589182.

31. SOBOL A., 2017, Inteligentne miasta versus zrównoważone miasta, Studia Ekonomiczne, Zeszyty Naukowe Wydziałowe Uniwersytetu Ekonomicznego w Katowicach, 320: 75-86.

32. SZCZECH-PIETKIEWICZ E., 2018, Konkurencyjność miast: analiza zjawiska na przykładzie polskich miast wojewódzkich, Oficyna Wydawnicza SGH, Warszawa.

33. TABAKOW M., KORCZAK J., FRANCZYK B., 2014, Big Data - definicje, wyzwania i technologie informatyczne, Informatyka Ekonomiczna, 1(31). 